\title{
Traces of Human Life Style from the Palaeolithic Era to the Beginning of the First Century AD
}

\author{
I Made Suastika
}

\section{Introduction}

The Importance of the Archaeological Research in North Bali

Prehistoric life in Bali can be characterized as a life of hunters and gatherers. This description is based on the cultural evidence known to have been Palaeolithic, in the form of solid tools discovered around Lake Batur, Trunyan, Kintamani, Sembiran, Pacung, Julah, and Bondalem (Soejono 1984:107; Suastika 2000a). Although the material evidence has been discovered, the people who supported the culture and who created the solid stone tools have so far not been identified.

It seems that there was continuous life in Bali as far as can be deduced from the natural caves used as settlements. Traces of Mesolithic culture have been identified from discoveries made in the cave at Selonding, Pecatu. The tools are of bones and horn; nothing is known, however, of the people who made them (Soejono 1984:98). In addition to the cave at Selonding I recently discovered some caves on Nusa Penida. The excavations in the Goa Gede there showed two cultural layers of the hunting and gathering continuum, together with an additional layer of cultivation. In the agricultural layer some C14 dating has been carried out, in cooperation with Brigitta Hauser-Schäublin, Institute for Cultural and Social Anthropology, University of Goettingen, and P. M. Grootes, Leibniz Laboratory 
for Radiometric Dating and Stable Isotope Research, Kiel, which has produced dating of $3805 \pm 25$ BP (Suastika 2005).

With the beginning of agriculture, people started living permanently in small settlements. Agriculture and the pattern of living permanently in small settlements contributed to an increasing population density, the development of a clan-based society and elaborate forms of cooperation in the cultivation of agricultural land as well as complex activities relating to death and worship in general. Forms of worship such as the menhir (a big stone post as a megalithic cultural product symbolizing the ancestor's soul), the stone seat (the "king's chair" made of stone), statues and other megalithic monuments were developed in honour of the ancestors. As other excavations along the north coast of Bali have shown, the megalithic tradition appeared in the agricultural farming period and continued to develop to the Bronze-Iron Age (perundagian) up to the present day (Heekeren 1958; Soejono 1982; Sukendar 1993; Sutaba 1976).

Pacung is one of the archaeological sites located in the north-eastern coastal area of Bali. Like other ancient villages such as Bangkah, Julah, Sembiran, Bondalem, Tejakula, Les and Penutukan, Pacung has unique traditions manifested in its worship system, its form of social organization, the rules governing social life and the ancient artefacts that have been discovered there

This paper will discuss the above-mentioned traces of human life based on the archaeological research carried out at Pacung and its surroundings.

The archaeological research in North Bali has been crucial for the development of archaeology as a discipline in Indonesia in general and in Bali in particular. The results gave evidence of Bali's long history predating the establishment of Dutch colonial rule by centuries, even millennia; the results, therefore, have proved to be an important contribution to Bali's identity. The archaeological research started with the deciphering of inscriptions kept at Sembiran by R. Goris (1954). In 1961 R.P. Soejono conducted research at Sembiran and excavated some Palaeolithic tools (Soejono 1962:225).

A few years later, I Made Sutaba discovered some megalithic buildings there, which he interpreted as prehistoric in origin. At about the same time, I Wayan Widia investigated a bronze kettledrum, nekara, used in religious ceremonies during the Bronze Era decorated with an eleven-sided star; this kettledrum was $84 \mathrm{~cm}$ high and had a diameter of $62 \mathrm{~cm}$. This important artefact, whose whereabouts are unclear today, was found by chance by some inhabitants at Pacung village. This drum has been identified as belonging to the same type as the existing at Pejeng (Widia 1981). Then, in 1987 I Wayan Ardika started excavations at Bangkah, Pacung and Sembiran. His research produced a wealth of data, among them sherds of local pottery and foreign ceramics, fragments of a kettledrum, beads, and so on (Ardika 1989). Since then researchers have paid so much attention to the site that it has even been used as a training field for students, through cooperation between 
the Archaeological Office of Denpasar and the Faculty of Letters, Udayana University, a project intensified since 1990.

In addition, archaeometric research was conducted by the National Archaeological Research Centre of Jakarta in 1995 under the leadership of the archaeologist Sudiono in order to establish the relationship between the cultural and the environmental variables so that the choice and the location of Sembiran as the settlement location in the past could be reconstructed. After 1995 the research was continued by the Department of Archaeology, the Faculty of Letters at Udayana University, in cooperation with the National Archaeological Research Centre through the Archaeology Office at Denpasar.

From the typology of findings, their stratigraphic location and comparison with similar findings in other regions, we can conclude that the north-eastern coast had been inhabited since the Neolitihic (perundagian) that is, from the first Millennium BC to the first century AD (Sudiono and Arfian 1995). The excavation campaigns mentioned above have produced many archaeological remains. Various Palaeolithic tools, so-called choppers and smaller tools, flakes and blades (serpin bilab), various kinds of pottery sherds of both local and foreign origin (made in India), a large variety of beads, bronze fragments of kettledrums, human remains and animal bones, stone seats ("king's chair"), statues, stone piles, and sarcophagi. Still, many of the archaeological artefacts and the cultural context they come from need further study and interpretation.

\section{The Location of Pacung}

Morphologically, the northern part of Bali is divided into three regions: the coastal region, the mainland region and the hilly region (Figure 1).

Administratively, Pacung village belongs to Tejakula District, Buleleng Regency. The site can be reached easily by any means of transport. It is 26 kilometres from Singaraja city, or 112 kilometres from Denpasar city. Geographically, reckoned from the meridian spot in Jakarta, the position of the site is $8^{\circ} 7^{\prime} 57^{\prime \prime}$ to $8^{\circ} 11^{\prime} 42^{\prime \prime}$ South Latitude and $115^{\circ} 12^{\prime} 30^{\prime \prime}$ to $115^{\circ} 15^{\prime} 49^{\prime \prime}$ East Longitude and 0 - 350 metres above sea level.

Pacung is situated on a narrow strip of land between the mountains and the sea. The soil is brown and yellow in colour. Water is available only near the coast; rice cultivation is not possible. Geologically, the substratum consists of tuff stones, and the sediment of old Buyan and Beratan lava composed of lava, breccia and tuff that had erupted from Mount Kalatakan, Mount Merbuk and Mount Patas (West Bali) (for a geological map of Northeast Bali see Kalb, this volume, Figure 3).

The environmental conditions are so bare that land conservation today is not possible in the way as on the hills with dense forest. Mountains without forest as a binding agent are prone to high erosion during the wet season. This has been evidenced by the floods and landslides that frequently strike the inhabitants' 
houses. Due to these conditions, most villagers in Pacung village and its surroundings currently work as farmers cultivating dry fields or gardens. Some also work as traders and fishermen.

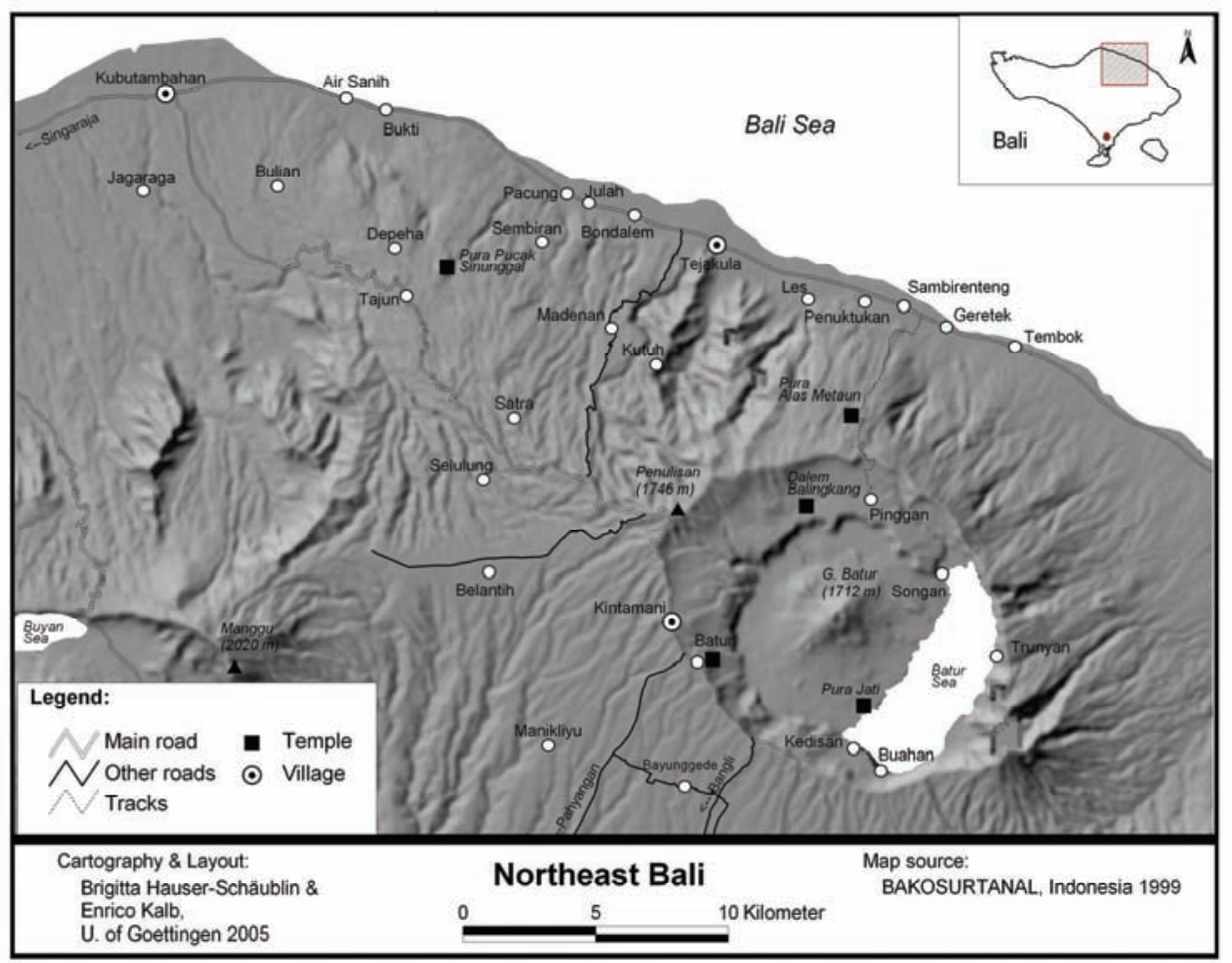

Figure 1: Northeast relief of Bali with the huge crater and caldera of the Batur volcano.

\section{The Results of the Excavation at Pacung}

The Oldest Traces of Human Life

Natural conditions supporting human life during the Pleistocene Era that commenced from 2.500 .000 to about 10.000 years ago were marked by major incidents affecting human life. Such incidents included the expansion of ice on the earth's surface, the fluctuation of sea level, volcanic eruptions, and the appearance and disappearance of rivers and lakes.

In Indonesia the Pleistocene Era is chronologically divided into the formations of Pucangan (Earlier Pleistocene; named after a location in eastern-central Java), Kabuh (Middle Pleistocene) and Notopuro (Upper Pleistocene). These eras are clas- 
sified as the hunting and food collecting periods which occurred from 1.9 million to 10.000 million years ago (Soejono 1976:20). Excavations at Sangiran (Central Java) proved that Homo erectus dominated this region from the Earlier Pleistocene to Middle Pleistocene. This period of time corresponds to 1.3 to 0.2 million years ago (Widianto et al. 1998:1). Nevertheless, natural conditions from the earliest era of mankind in Indonesia, the Pleistocene, were favourable for these forebearers of modern man. The people lived in groups and subsisted from hunting and gathering; they made and used all kinds of Palaeolithic tools including heavy ones ("pebbles"), flakes, bones, antler tool, and wooden ones.

In the Palaeolithic tradition there are two well-known basic forms. These are stone tools called choppers (a kind of axe) and flakes (Soejono et al. 1984:84). Basically, the method by which choppers were produced was unifacial, combining both solid and rough characteristics. Similarly, the flakes seldom show a point of percussion or a striking platform (Heekeren 1955:11).

In Indonesia the Palaeolithic tools were mostly stone tools which are typologically similar to those wide-spread in other parts of Southeast Asia and East Asia. They developed in the regions that had a lot of stone materials suitable for producing tools. This can be seen in the regions where Palaeolithic developed in Indonesia such as in Java, Sumatra, Nias, Kalimantan, Sulawesi, Lombok, Sumbawa, Flores, Timor, Sabu and Sumba. In Bali Palaeolithic stone tools were discovered around Lake Batur, Sembiran, Julah and Pacung.

Geologically, the mountainous area in North Bali is an extension of the Solo Zone in Java. This zone is a volcanic belt that formed after the Lower Pleistocene Era and is still active today. The Mount Batur complex is actually a big crater formed by volcanic eruptions resulting in two crater rims (caldera) including the ridge on which Sembiran is situated. Many Palaeolithic tools have been discovered on this ridge, which includes Pacung and Julah villages. Research on Palaeolithic tools was first conducted by R.P. Soejono, who made a typological classification of the tools (Soejono 1962). In 1990 I conducted further research at Sembiran, Pacung and Julah. I found Palaeolithic tools in different locations, such as at the lower and the upper parts of the River Panggang, near Sembiran and close to the river Kayehan Kangin, also along a path near Julah and in the lowland plain close to Pacung.

By means of technological analysis I was able to classify them as: chopper (both general and iron type), chopping tool, proto hand axe, hand adze, hand axe, high scraper, and another kind of scraper, hammer and various other tools (Suastika 2000a; 2000b).

Compared with other Palaeolithic sites in Indonesia, the Pacitan Palaeolithic tools (named after a village in south-central Java) are the best both quantitatively and qualitatively. Pacitan Palaeolithic tools showed a development of both the solid sort (choppers) and flakes, which were classified by Movius (1948). Technologically, van Heekeren (1922:3) believed that the tools found in Pacitan were 
flakes struck from cores (Bellwood 1985:60-63). After striking one stone against another or throwing one stone against a bigger one, the so-called "smashing technique", the good and suitable fragments were selected to be used as tools. This technique seems to have been already widely used in the Palaeolithic Era. The tools found at Pacung and Sembiran are of the same type. The stone tools are simple in form and are roughly trimmed. More developed types of tools have not been discovered at Pacung so far. The reason for this may be that the stone material in Sembiran and its surroundings is rougher and harder than the stone found at Pacitan.

In 1990 I collected a number of Palaeolithic tools found spread over Pacung, Sembiran and Julah, which are in the form of solid tools including choppers, scrapers, chopping tools, hand adzes, proto hand axes, hand axes, axes of a horsehoof type, hammers and core (Table 1).

Table 1: The Range of Palaeolithic Tools Found at the Pacung Site

\begin{tabular}{|l|l|l|l|l|l|l|l|l|l|}
\hline Location & Chopper & $\begin{array}{l}\text { Hand } \\
\text { axe }\end{array}$ & $\begin{array}{l}\text { Hand } \\
\text { adze }\end{array}$ & $\begin{array}{l}\text { Chop- } \\
\text { ping tool }\end{array}$ & Scraper & Flake & Core & $\begin{array}{l}\text { Ham- } \\
\text { mer }\end{array}$ & $\begin{array}{l}\text { Oth- } \\
\text { ers }\end{array}$ \\
\hline $\begin{array}{l}\text { Pacung } \\
\text { village }\end{array}$ & 10 & 2 & 2 & 2 & 8 & 5 & - & 1 & 30 \\
\hline $\begin{array}{l}\text { Coastal } \\
\text { area }\end{array}$ & 6 & 9 & 2 & 2 & 9 & 1 & 2 & - & 31 \\
\hline $\begin{array}{l}\text { Sembiran } \\
\text { village }\end{array}$ & 9 & 3 & 2 & 1 & 6 & - & 2 & - & 23 \\
\hline $\begin{array}{l}\text { Julah } \\
\text { village }\end{array}$ & 3 & 6 & 1 & 1 & 6 & 2 & - & - & 19 \\
\hline Total & 28 & 20 & 7 & 6 & 29 & 8 & 4 & 1 & 103 \\
\hline
\end{tabular}

The Palaeolithic tools are dominated by choppers. Among them, 14 are of the horse-hoof type. Their characteristics are as follows: the material is basalt stone black in colour, the sharpened part is semi-circular and made by upright trimming, and the outer layer of the stone is sometimes left on the surface. In addition to the choppers of the horse-hoof type, four items of the iron types are also found. Their characteristics are as follows: they are long, plano-convex cross-section, strictly trimmed and stretched. On the sharpened part, marks of frequent use can be seen. Marks of use are also seen on the other tools such as on chopping tools, hand axes and hand adzes (Suastika 1990:5).

\section{Neolithic Evidence}

Human life in the Agricultural Era (Neolithics) - starting about 5000 years ago was, as in other parts of the world, a more developed level (Ardika 1987, Ardika 
and Sutaba 1996). The tools were well made, polished and und rubbed to make them soft and sometimes shiny.

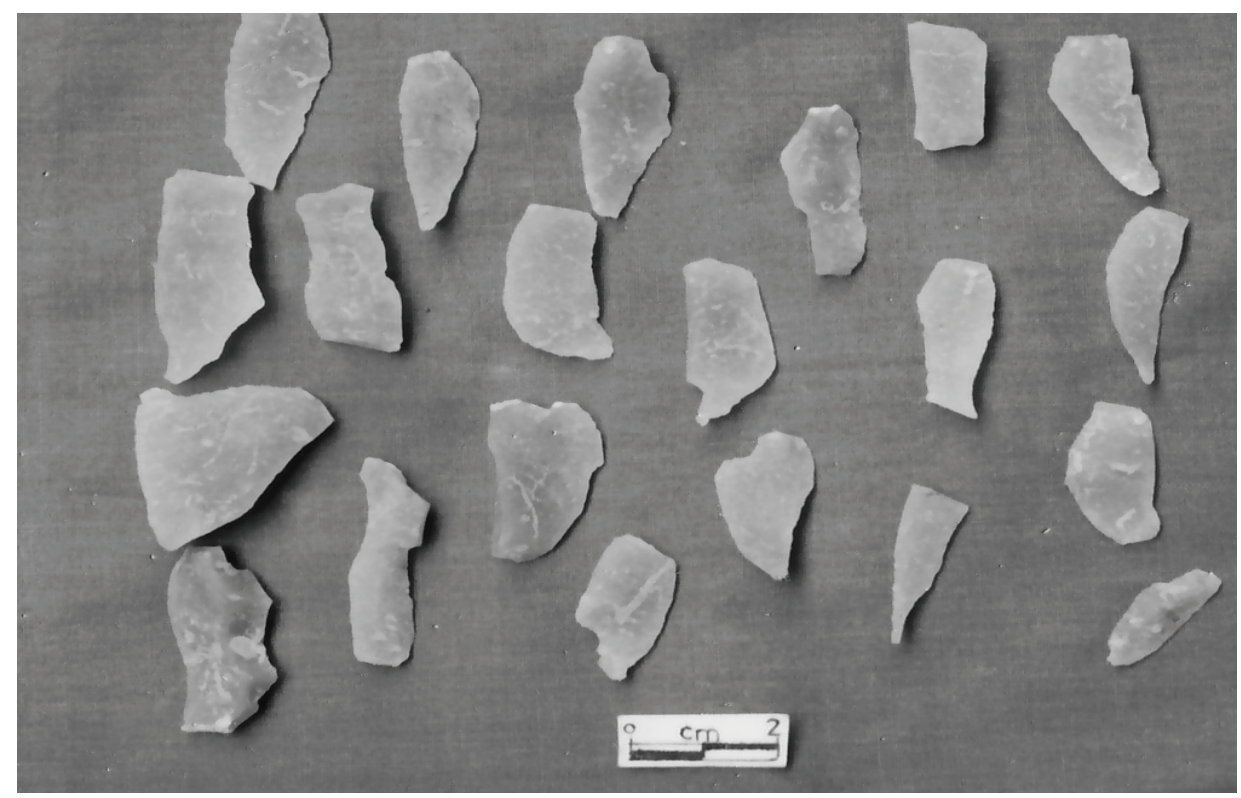

Photo 1: Flakes and blades used as grave goods, Pacung excavation. Photo: IMade Suastika

The Neolithic or Agricultural Era coincided with the development of expertise in polishing stone tools and pottery production. The surface finding of a one-sided hatchet, polished on all sides, is an interesting example. It is rectangular with a sharpened monofacial edge. In addition, obsidian tools, employed as grave goods, were found at Bondalem beach. On one of the skeletons in Pacung, which followed the system of burial without containers, the head was directed mountainward and the feet towards the sea. Near the shoulders 21 obsidian flakes and blades were found and on the feet one clay pot (Sudiono and Arfian 1995:21). The core flakes in Indonesia had appeared after the Mesolithic Era, but at the Pacung site these tools were associated with pottery used as grave goods. This clearly reveals that flakes played an important role during the Cultivation Era, too. The skeleton found was incomplete and in a fragile condition. The remains consisted of an upper and lower arm bone, and a left and right and upper right skin bone. The skull was damaged and the teeth incomplete. The position of the skeleton was five metres north of the shore edge, buried 210-260 centimetres below sea level. The analysis of the flakes and blades revealed slightly damaged edges, showing that the tools had been regularly used before. 
The excavations of graves containing human skeletons showed that the people living at different places along the coast, and also in Bondalem, had been familiar with the same burial system.

In the Pacung/Sembrian area, fragments of containers (of unknown use) had been found; there is however almost no documentation on these excavations. Most recently (in the late 1990s) a sarcophagus was discovered at the temple of Ponjok Batu during renovation works. However, most of these graves excavated along the coast between Pacung and Tejakula did not display any permanent container such as sarcophagi. The burials showed in each case no traces of containers and the corpse was stretched out. Not far from where the skeleton was found in Pacung, a burial jar with a lid, which first appeared when the sea level retreated, was also found. The jar was found damaged. The wall of the container is thin and blackish-brown in colour; there is no indication that the jar was produced by means of a rotating wheel. The lid is thick and yellowish-brown in colour. The diameter of the jar is $60-68 \mathrm{~cm}$ and the height is $40 \mathrm{~cm}$. The position of the jar was $2.80 \mathrm{~m}$ from the shore edge and $2.60 \mathrm{~m}$ below sea level. The jar contained an intact skull, human bones, teeth and burned pig bones. The jar burial (secondary burial) was located beside the primary one mentioned above. The association of flakes and blades, skeletons and pottery as grave goods suggest that these burials are not Mesolithic but Neolithic, since pottery is characteristic of Neolithic culture.

The fragments of pottery both of local and Indian origin are the most dominant artefacts found at the Pacung site. The fragments of local pottery consist of both simple and ornamented ones. They comprise the lip parts, the body, the base, the carination, and the pin and handle of a pitcher. The data used for the analysis were the findings in excavation Test Pit I and Test Pit II, which were excavated by the Archaeology Office of Denpasar, and those in Box I, II, III, IV and V, which were excavated by the Archaeology Department of the Faculty of Letters, Udayana University. 


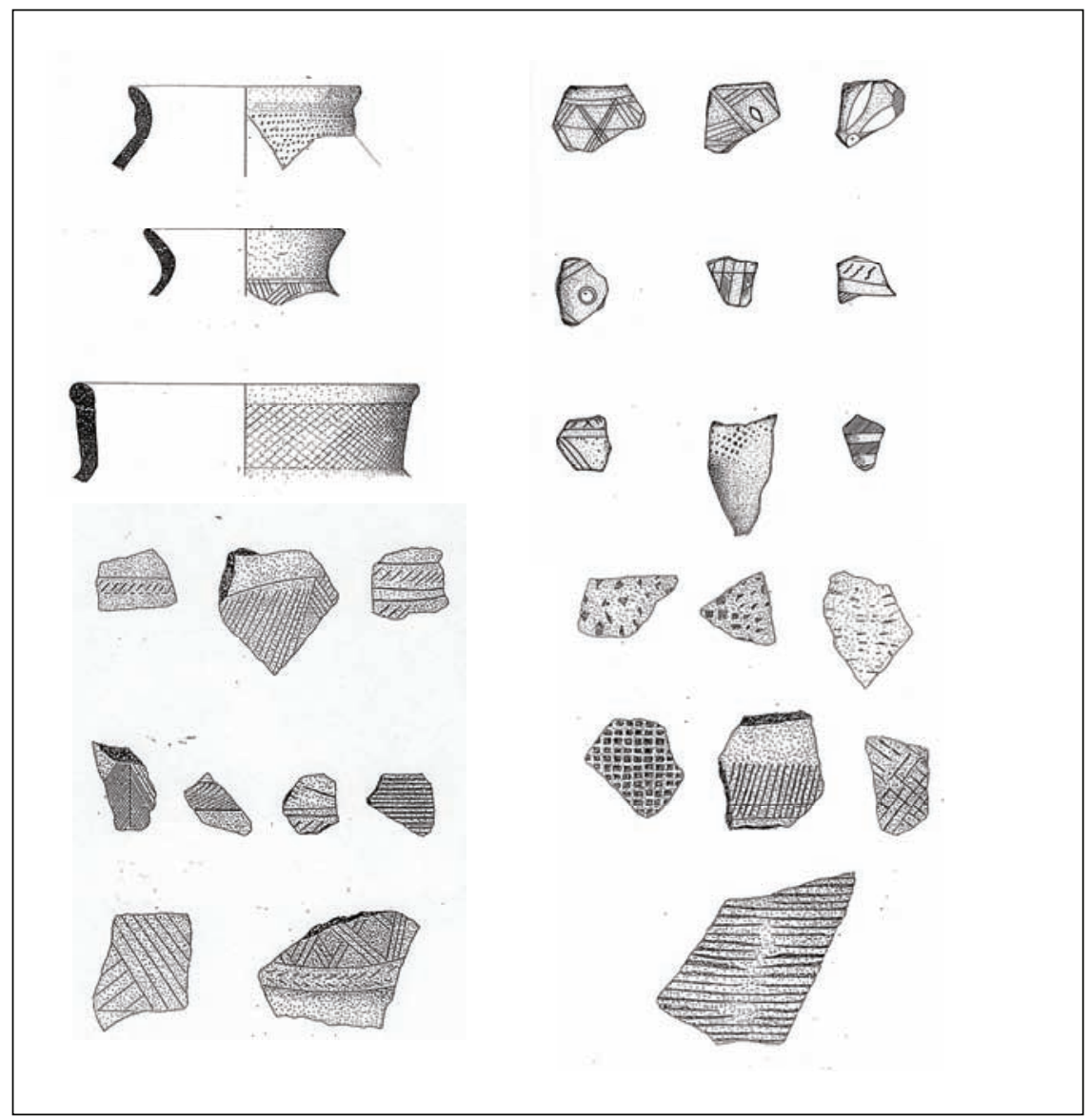

Figure 2: Pottery sherds displaying different techniques and styles of decoration, Pacung Site.

Drawing by Tim Jurusan Arkeologi 2004.

The findings of local pottery in Test Pit (TP) I amounted to 4.000 pieces, altogether consisting of pieces of simple pottery totalling 4.061 and ornamented ones totalling 339. The findings in Test Pit II amounted to 1.816, consisting of 1.731 pieces of simple pottery and 85 ornamented ones. Those in trench PCN I amounted to 2.342 , consisting of 2.326 fragments of simple pottery and 16 fragments of ornamented ones. Those in trench PCN II totalled 14.083, consisting of 13.146 fragments of simple pottery and 937 ornamented ones. In trench III, the fragments of pottery totalled 2.792, consisting of 2.507 fragments of simple pottery and 285 ones of ornamented pottery. Trench PCN IV contained 16.952 fragments of pottery, consisting of 16.068 fragments of simple pottery and 884 ones of ornamented pottery. Trench PCN V contained 292 fragments, 209 of which were of 
simple pottery and 83 of ornamented pottery. The total amount of the findings was 42.277 , with fragments of simple pottery (table 2) predominant.

Table 2: Distribution of Findings of Local Pottery, Pacung Site, Buleleng

\begin{tabular}{|c|c|c|c|c|}
\hline \multirow{2}{*}{ Number } & \multirow{2}{*}{ Trench } & \multicolumn{2}{|c|}{ Fragments of Local Pottery } & \multirow{2}{*}{ Total } \\
\cline { 3 - 4 } & TP I & Simple & Ornamented & 4,061 \\
\hline 1 & TP II & 1,731 & 339 & 45 \\
\hline 2 & PCN I & 2,326 & 16 & 1,816 \\
\hline 3 & PCN II & 13,146 & 937 & 2,342 \\
\hline 4 & PCN III & 2,507 & 285 & 14,083 \\
\hline 5 & PCN IV & 6,068 & 884 & 16,792 \\
\hline 6 & PCN V & 209 & 83 & 2952 \\
\hline 7 & Total & 40,028 & 2629 & 42,277 \\
\hline
\end{tabular}

The techniques of making ornaments on the pottery at Pacung were the impressed technique (paddle-impressed and dentate stamped), the incised technique and the excised technique. The ornamental patterns varied. Some were in the form of repeated circles, some were in the form of straight lines, some were in zigzag, lozenges, and others were in the form of curved lines, fish bones, rectangles, or a combination of all types.

The varied ornamental patterns on the local pottery are highly artistic. The ornamental patterns are similar to those found at burial sites in other parts of Bali such as Gilimanuk (Jembrana Regency), Manikliu (Bangli Regency) and Jambe (Tabanan Regency).

The Pacung site and its surroundings contain a large number of pieces of pottery brought from outside Bali, in particular India. The Indian pottery was also of various forms and contained fragments of Indian Rouletted Ware. Features of the latter were that the surface and the inside part of the wall were soft thanks to the advanced technique used in their manufacture. The core colour was light grey, brown, light orange and black. These features show similarity with rouletted pottery which was classified by Wheeler (1946) as "Arikamedu pottery type 1". The Neutron Activation Analysis (NAA) conducted by I Wayan Ardika shows that the fragments of Indian pottery are identical in composition to those of the Arikamedu, Karaikadu (both in South India) and Anuradhapura (Sri Lanka) type (Ardika 1991; Soegondo 2002:216-218).

In reconstructing the forms, types and functions of pottery all the parts of the pottery covering the lip, the rim, the neck, the body, the base, the carination, the lid and the spout, were subjected to analysis. Some of the Indian pottery consisted of ornamented or plain cups, bowls, pans and water jars, obviously intended for everyday use. 
Chemical analysis of the pottery found at Sembiran showed a composition of silica, calcium, sodium, magnesium, aluminium and sulphate (Ardika et al. 1996).

The beads found at Pacung were made of various materials such as stones, glass and fish bones. Among them, glass is the most dominant. Some were round, some were rectangular and the rest had a cylindrical form. Among them, the round ones were the most dominant. The colours also vary: some were white, some were blue, some were dark red, some were orange, some were greenish yellow and some were green with spots. Most beads were found in association with human skeletons and pottery.

Some of the bronze fragments found during the excavations at Pacung, Bangkah and Sembiran were fragments of kettledrums and of bronze bracelets. Some flat fish hooks with a hole in the middle, relatively small and made of bronze and iron with a diameter of $1.5 \mathrm{~cm}$ were also found. Other bronze fragments of kettledrums and bracelets were found in association with pottery fragments along the north-western coast of Bondalem. Three further bronze bracelets were also found at the Pacung site near a skeleton which was in a flexed position. A kapak corong (a kind of axe), whose handle was in bad condition, was found at a depth of 4.4 metres by some local people while digging a well at Pacung (Sudiono and Arfian 1995:21).

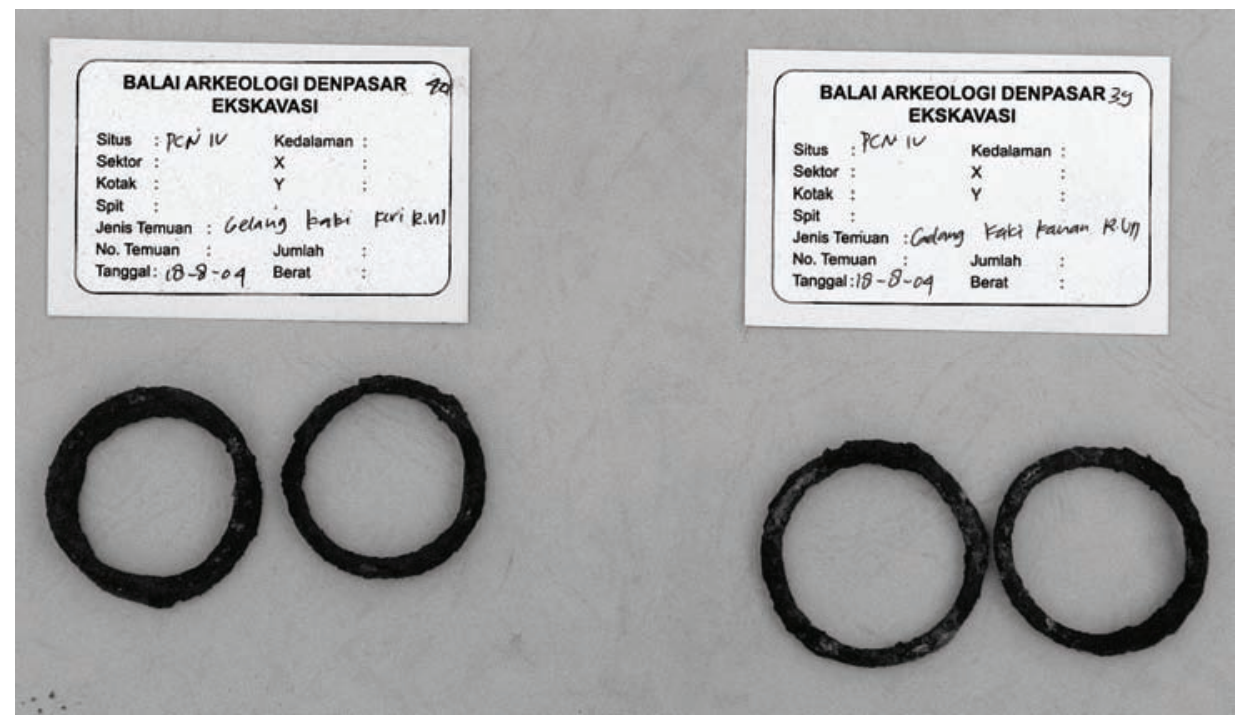

Photo 2: Bronze rings found at Pacung.

Photo: Jörg Hauser 2004.

The metal artefacts, especially those made of bronze, show that the coastal community living at Pacung was already familiar with bronze tools in their daily lives. Indeed, this was a feature of life in the first century AD. 
Apart from burials, a building foundation made of basalt gravel in trench $\mathrm{X}$ and trench XI was found at the Pacung site, too. The foundation shows a rectangular ground plan; the house was possibly built on wooden or bamboo poles.

A fireplace was found in trench II at the Sembiran site $30 \mathrm{~cm}$ below the surface. It was composed of four stones as supports. Fragments of an earthenware pan and charcoal were found surrounded by the stones. One earthenware pan containing betel lime at the edge of the fireplace was found, reminding us of the habit of keeping betel lime in a pan at the fireplace in the kitchen close to the drinking water container (Suantika 1991:35).

During the Neolithic Era, people resided permanently in villages and arranged their lives in accordance with their collective needs, which focused on how to manage a subsistence economy by means of both farming and animal husbandry. In the Bronze-Iron Age people developed the technique of forging metal for creating various tools. The progress achieved by people in improving their living standard led to a more complex structuring of society. The division of labour became more diverse with specialists for different tasks. Among them were undagi, craftsmen who specialized in various kinds of construction work, such as building wooden houses and producing goods made of pottery and other material as well (Soejono et al. 1984:238).

Further specialists produced canoes, bronze kettledrums, bronze hoes and so on. Metal technology developed fast at the beginning of the first century AD. This can be seen from the findings discovered by excavation and survey in the Pacung area; they all display features typical of the Bronze-Iron Age.

Agriculture became a more sophisticated activity, especially when the rice fields were supplied with water in order to set up irrigation agriculture and wet rice cultivation.

The organic remains found in the graves can be assumed to be the remains of human and animal bones. In addition to the fragments of bones some entire human skeletons were also found. Radiocarbon dating gives an estimated age of $2105 \mathrm{BP}$ for human bones found at a layer of $4,3 \mathrm{~m}$; as the tables (at the end of this chapter) show. The analyzing Laboratory added the comments: "The natural heavy $\delta{ }^{13} \mathrm{C}$-values may suggest a $\mathrm{C} 4$ [usually related to the consumption of crops such as millet, maize, sugar cane and others, but not rice], or a fish component in alimentation".

Furthermore, DNA laboratory analysis for a number of human teeth found at the Pacung site has already been done revealing that one of the human skeletons at the Pacung site displayed traces of probably north-east Indian ancestry. This was the skeleton of an adult female who lived 50 years before the first century AD. This strongly supports the assumption that Bali had been visited by Indians in person since the first centuries BC (Tim Jurusan Arkeologi 2003:46). Previously, scholars had debated the question whether the artefacts of Indian origin had reached Bali through indirect trade relations only. 
The Bronze-Iron Age was a so-called minor tradition which developed fast in Bali and continued up to the time when the influence of Hinduism, a major tradition, was introduced. The mix of the two traditions has resulted in the cultural tradition peculiar to Bali today.

\section{Summary}

Based on the data obtained from earlier research, excavations and surveys, it can be stated that the Pacung site has been continuously settled by humans since the Palaeolithic Era.

The flakes and blades, usually attributed to the Mesolithic Era, that were found in association with pottery sherds provided as grave goods are evidence for agricultural life, as is the sided hatchet. Therefore, Mesolithic and Neolithic life styles and their corresponding tools cannot be neatly separated, as is often assumed in archaeology. In this era people already permanently settled, and consequently, matters relating to fertility, crop diseases, safety and protection seem to have received much attention resulting in religious beliefs and practices that were directed probably towards the ancestors. The megalithic constructions are likely to have been related to ancestor worship.

Around the first centuries AD, or by the time Hinduism was brought in, the life at Pacung was becoming developed and more complex. This can be shown by the discovery of a refined metal-producing tool, that is, a mould used for melting metals, especially bronze. The metal artefacts found were bronze bracelets, bronze kettledrums, and bronze axes which were used as daily tools, ceremonial equipment and grave goods. The tradition of secondary burial in containers such as the jar found at Pacung site has also been known from other sites in Indonesia connected to the Bronze-Iron Age.

\section{References}

Ardika, I Wayan et al.

1987 Bronze Artifacts and the Rise of Complex Society in Bali. M.A. Thesis. Canberra: Australian National University.

1989 Laporan Ekskavasi Arkeologi di Situs Sembiran dan Pacung, Kecamatan Tejakula, Buleleng. Denpasar: Fakultasa Sastra, Universitas Udayana.

1991 Archaeological Research in Northeastern Bali. A Thesis Submitted for the Degree of Doctor of Philosophy at the Australian National University. Canberra: Australian National University.

1996 Ekskavasi Arkeologi di Situs Sembiran. Kecamatan Tejakula, Kabupaten Buleleng.

Ardika, I Wayan and I Made Sutaba (eds.)

1996 Dinamika Kebudayaan Bali. Denpasar: Upada Sastra. 
Grootes, P.M.

2004 Datierungsergebnisse der Knochenproben 25125, 25126. Unpublished Report. Leibniz Labor für Altersbestimmung und Isotopenforschung. ChristianAlbrechts-Universität Kiel..

Goris, R.

1954 Prasasti Bali. Lembaga Bahasa dan Budaya. Fakultas Sastra dan Filsafat, Universitas Indonesia. Bandung: Masa Baru.

Heekeren, H. R. van

1955 (1992) New Investigation on the Lower Paleolithic Culture in Java. Berita Dinas Purbakala, Bulletin of the Archaeological Service of the Republic of Indonesia, Vol. 1; Repr. Djatop. 660/ BC.-1.000 bk/ 55; Jakarta.

1958 The Bronze-Iron Age of Indonesia. Verhandelingen van het Koninklijk Instituut voor Taal-, Land- en Volkenkunde, Vol. XXII. 's-Gravenhage: Martinus Nijhoff.

Movius, Jr. H.L.

1949 The Lower Palaeolithic Cultures of Southern and Eastern Asia. Transactions of the American Philosophical Society 38, 4, (new series); pp. 329-340. Philadelphia: The American Philosophical Society.

Soegondo, Santoso

2002 Gambaran tentang Gerabah Situs Sembiran: Pembahasan tentang Disertasi I Wayan Ardika, Kumpulan Makalah Pertemuan Ilmiah Arkeologi VIII. Jakarta: Ikatan Ahli Arkeologi Indonesia.

Soejono, R.P.

1962 Primary Notes on New Finds of Lower Paleolithic Implements from Indonesia, Asian Perspectives V: 217- 233.

1976 Tinjauan tentang Pengkerangkaan Prasejarah Indonesia. Aspek-Aspek Arkeologi Indonesia, Vol. 5. Jakarta: Departement Pendidikan dan Kebudayaan (PPKPN).

1982 On the Megalithic in Indonesia. Megalithic Cultures in Indonesia, Monographs Vol. 2. Singapore: Hanyang University Press.

Soejono, R.P. et al.

1984 Jaman Prasejarah di Indonesia. Sejarah Nasional Indonesia, Vol. I. Jakarta: Departemen Pendidikan dan Kebudayaan.

Suantika, I Wayan

1991 Ekskavasi Situs Bangsal Desa Tejakula, Kecamatan Tejakula, Kabupaten Buleleng. Laporan Penelitian Arkeologi. Denpasar: Balai Arkeologi Denpasar.

Suastika, I Made

1990 Diskripsi Alat-Alat Batu. Hasil Penelitian Situs Pacung dan Sekitarnya. Laporan Penelitian Arkeologi. Denpasar: Pusat Penelitian Arkeologi Nasional, Balai Arkeologi.

2000a Analisis Teknologis Alat-Alat Paleolitik Sembiran. Bulletin Prasejarah/ Bulletin of Prehistory, Vol. I. Jakarta: Asosiasi Prehistori Indonesia.

2000b The Paleolithic Tool From Bali. Forum Arkeologi, Vol. 1:46-58. Denpasar: Balai Arkeologi Denpasar. 
2005 Menapak Kehidupan Gua di Nusa Penida, Bali. Berita Penelitian Arkeologi. Denpasar: Badan Pengembangan Sumberdaya Kebudayaan dan Pariwisata, Pusat Penelitian dan Pangembangan Arkeologi Nasional.

Sudiono and Arfian

1995 Penelitian Arkeometri di Situs Sembiran, Kecamatan Tejakula, Kabupaten Buleleng, Propinsi Bali. Laporan Penelitian Arkeologi Bidang Arkeometri. Jakarta: Pusat Penelitian Arkeologi Nasional.

Sukendar, Haris

1993 Arca Menhir di Indonesia. Fungsinya dalam Peribadatan. Jakarta: Universitas Indonesia.

Sutaba, I Made

1976 Megalithic Traditions in Sembiran North Bali, Aspek-Aspek Arkeologi Indonesia, Vol. 4. Jakarta: Pusat Penelitian Arkeologi Nasional.

Tim Jurusan Arkeologi

2003 Hasil-Hasil Penelitian Situs Pacung Kecamatan Tejakula. Denpasar: Laporan Penelitian Fakultas Sastra Universitas Udayana.

2004 Laporan Penelitian Ekskavasi Arkeologi di Situs Pacung, Kecamatan Tejakula, Buleleng. Denpasar: Fakultas Sastra, Universitas Udayana.

Wheeler, R.E.M., Ghosh, A. and Krishna Deva.

1946 Arikamedu: an Indo-Roman Trading Station on the East Coast of India. Ancient India 2: 17-124.

Widia, I Wayan

1981 Temuan Nekara Perunggu Tejakula. Saraswati 17. Denpasar: Muesum Bali.

Widianto, Harry et al.

1998 Penelitian Situs Sangiran: Eksistensi Artefak pada Awal Kala Plestosen Tengah dan Stratigrafi Endapan Teras di Atas Seri Kabuh dan Seri Notopuro. Berita Penelitian Purbakala Daerah Istimewa Yogyakarta, Balai Arkeologi. Yogyakarta: Pusat Penelitian Arkeologi Nasional, Departemen Pendidikan dan Kebudayaan. 
Table 3a: Dating Results for KIA25125: 2004; S 6, Excavation Site Pacung

KIA25125 (PCN IV. S 6/II, Right Femur); Radiocarbon Age

2090BP \pm 37 ; Calibrated Age (2 Sigma): cat BC (196-4)

\begin{tabular}{|c|c|c|c|}
\hline Fraction & PMC (corrected) $)^{\dagger}$ & Radiocarbon-Age & $\delta 13 \mathrm{C}(\% 0)^{\ddagger}$ \\
\hline Bones, Collagen, $2.9 \mathrm{mg} \mathrm{C}$ & $77.09 \pm 0.26$ & $2090 \pm 25 \mathrm{BP}$ & $-17.12 \pm 0.07$ \\
\hline $\begin{array}{ll}\text { Radiocarbon Age: } & \text { BP }\end{array}$ & \multicolumn{3}{|l|}{$2090 \pm 27$} \\
\hline Calibrated Age: & \multicolumn{3}{|l|}{4} \\
\hline \multirow{3}{*}{$\begin{array}{l}\text { One Sigma Range: cal BC } \\
\text { (Probability 68,3\%) }\end{array}$} & \multicolumn{3}{|c|}{ (Probability $20.5 \%$ ) } \\
\hline & $119-88$ & \multirow{2}{*}{\multicolumn{2}{|c|}{$\begin{array}{l}\text { (Probability } 26.6 \%) \\
\text { (Probabilitv } 21.2 \%)\end{array}$}} \\
\hline & (Probab & & \\
\hline \multirow{3}{*}{$\begin{array}{l}\text { Two Sigma Range: cal BC } \\
\text { (Probability 95,4\%) }\end{array}$} & $196-192$ & \multicolumn{2}{|c|}{ (Probability $1.0 \%$ ) } \\
\hline & (Probab & \multicolumn{2}{|c|}{ (Probability $93.5 \%$ ) } \\
\hline & (Probab & \multicolumn{2}{|c|}{ (Probability 1.0\%) } \\
\hline
\end{tabular}

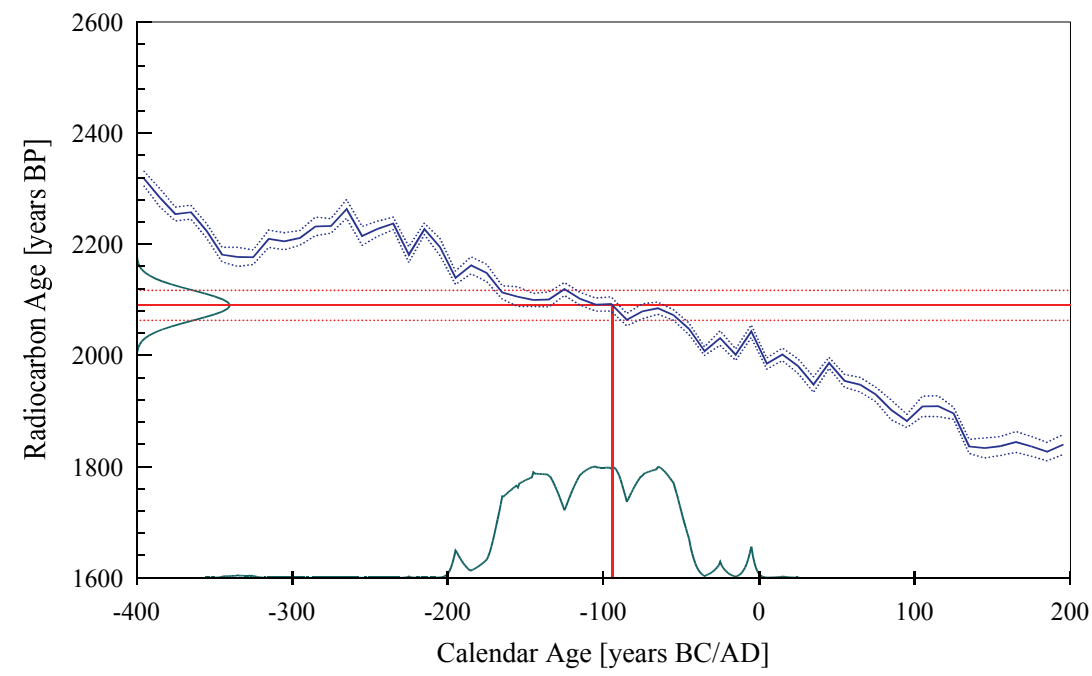

Calibrated age specified by:

Stuiver et al.

1998 „CALIB rev 4.3 (dataset 2)“, Radiocarbon 40, 1041 - 1083.

† "Corrected PMC" indicates the percent of modern (1950) carbon corrected for fractionation using the ${ }^{13} \mathrm{C}$ measurement. The indication " $>$ AD $1954 *$ " denotes the influence of bomb ${ }^{14} \mathrm{C}$.

$\ddagger$ Please note that the $\delta{ }^{13} \mathrm{C}$ includes the fractionation occurring in the sample preparation as well as in the AMS measurement and therefore cannot be compared to a mass-spectrometer measurement. 
Table 3b: Dating Results for KIA25125: 2004; S 6, Excavation Site Pacung

KIA25126 (CN IV. S 6/III, Left Humerus); Radiocarbon Age

2103BP \pm 37 ; Calibrated Age (2 Sigma): cal BC (198-47)

\begin{tabular}{|c|c|c|c|c|}
\hline \multicolumn{2}{|l|}{ Fraction } & PMC (revised) ${ }^{\dagger}$ & Radiocarbon -Age & $\delta^{13} \mathrm{C}(\%)^{\ddagger}$ \\
\hline \multicolumn{2}{|l|}{ Bones, Collagen, $3.8 \mathrm{mg} \mathrm{C}$} & $76.97 \pm 0.26$ & $2105 \pm 25 \mathrm{BP}$ & $-17.40 \pm 0.32$ \\
\hline $\begin{array}{l}\text { Radiocarbon Age: } \\
\text { Calibrated Age: } \\
\text { One Sigma Range: } \\
\text { (Probability 68, } 3 \% \text { ) } \\
\text { Two Sigma Range: } \\
\text { (Probability 95, 4\%) }\end{array}$ & $\begin{array}{l}\mathrm{BP} \\
\mathrm{cal} \mathrm{BC} \\
\mathrm{cal} \mathrm{BC} \\
\mathrm{cal} \mathrm{BC}\end{array}$ & $\begin{array}{ll}2103 \pm 27 & \\
151,134,116 \\
168-92 & \text { (Probal } \\
69-63 & \text { (Probal } \\
198-188 & \text { (Probal } \\
181-47 & \text { (Probal }\end{array}$ & $\begin{array}{l}\text { ty } 63.5 \%) \\
\text { ty } 4.8 \%) \\
\text { ty } 2.9 \%) \\
\text { ty } 92.5 \%)\end{array}$ & \\
\hline
\end{tabular}

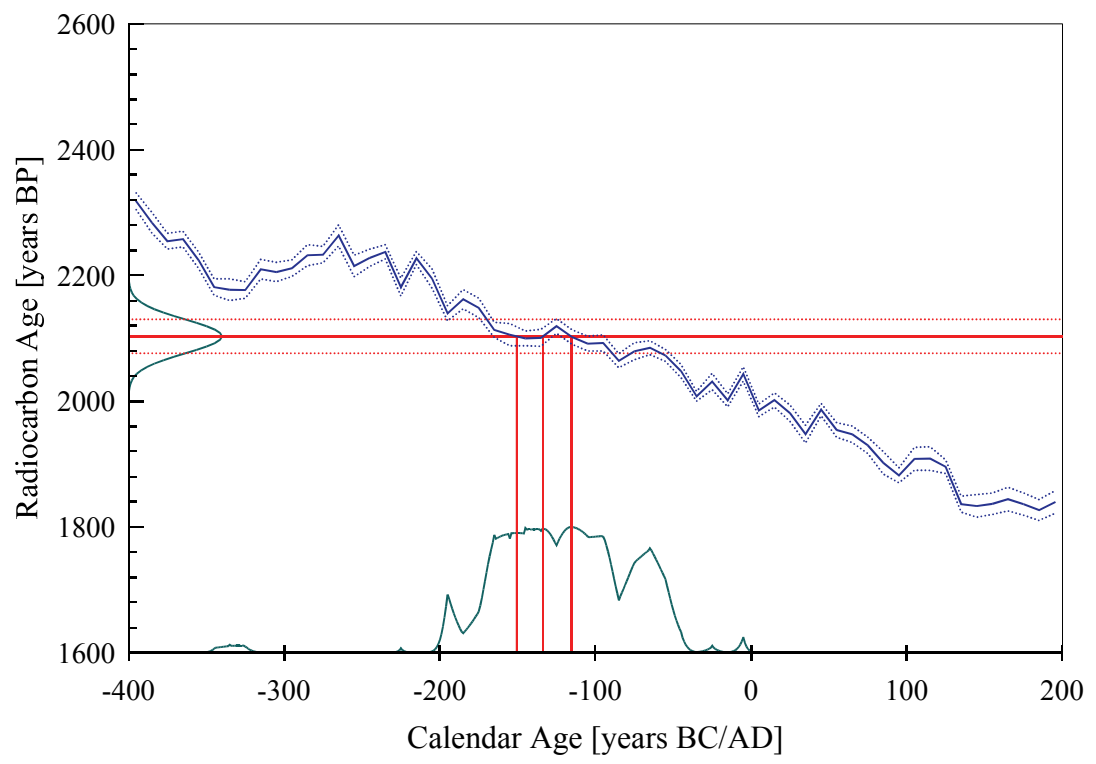

Calibrated age specified by:

Stuiver et al.

1998 „CALIB rev 4.3 (dataset 2)“, Radiocarbon 40, 1041 - 1083.

t "Corrected PMC" indicates the percent of modern (1950) carbon corrected for fractionation using the ${ }^{13} \mathrm{C}$ measurement. The indication "> AD 1954*" denotes the influence of bomb ${ }^{14} \mathrm{C}$.

$\ddagger$ Please note that the $\delta{ }^{13} \mathrm{C}$ includes the fractionation occurring in the sample preparation as well as in the AMS measurement and therefore cannot be compared to a mass-spectrometer measurement. 